\title{
Differentiation of decidual cells in mouse endometrial cell cultures
}

\author{
S. C. Bell and R. F. Searle \\ Reproductive Immunology Research Group, Department of Pathology, The Medical School, \\ University of Bristol, Bristol BS8 1TD, U.K.
}

\begin{abstract}
Summary. Mouse uterine cells were obtained by trypsinization of uteri at timed intervals after the induction of a decidual reaction by intraluminal instillation of arachis oil on Day 4 of normal pregnancy. Cells were also obtained from ovariectomized mouse uteri, some of which had received a progesterone-oestradiol sequence to sensitize the uterus to a decidual stimulus. The differentiation of decidual cells was followed in cultures of these cells. The morphology of the cells obtained after 6 days in culture was dependent upon the seeding density employed. At low seeding density (plating densities of 75-100 cells $/ \mathrm{mm}^{2}$ ) no net increase in cell number was observed, but large mononucleated stellate cells were present, with cytoplasmic and nuclear areas increased by 4 -fold. At higher seeding densities (plating densities of up to 709 cells $/ \mathrm{mm}^{2}$ ), a prolongation of cell survival and the appearance of substantial numbers of binucleated cells were observed. However, both cell types were characterized by the accumulation of filamentous material in the cytoplasm. Even at optimal seeding density the life-span of the decidualized cells could not be prolonged beyond 9 days. Uterine cells from hormone-treated ovariectomized animals underwent similar transformations but those from untreated ovariectomized mice gave only isolated islets of epithelial cells and scattered fibroblast-like cells in culture. These observations suggest that discrepancies in previous reports of in-vitro decidualization of rat uterine cells result from differences in the seeding densities employed.
\end{abstract}

\section{Introduction}

Endometrial stromal cells of the rat and mouse uterus in response to the implanting blastocyst or certain artificial stimuli undergo proliferation and differentiation resulting in the formation of the decidual cells of the decidua of pregnancy or the deciduoma of pseudopregnancy (De Feo, 1967; Finn, 1971; Psychoyos, 1973). The process, termed decidualization or the decidual cell reaction, has been studied in vivo at the morphological and, more recently, at the biochemical level (Denari, Germino \& Rosner, 1976; Ledford, Rankin, Markwald \& Baggett, 1976; Rankin, Ledford \& Baggett, 1977; Ledford et al., 1978; Moulton \& Blaha, 1978; Moulton, 1979; Serra, Ledford \& Baggett, 1979). The appearance of bi-, tri- and multinucleated cells, polyploid nuclear populations (Krehbiel, 1937; Leroy, Bogaert, Van Hoeck \& Delcroix, 1974) and of abundant thin cytoplasmic filaments (Tachi, Tachi \& Lindner, 1970) are constant features of early decidualization. Many of the biochemical parameters investigated in this system may reflect cellular growth, but more recent studies suggest that more specific alterations of protein synthesis are associated with the system (Yoshinaga, 1972, 1974; Glasser \& Clark, 1975; Bell, 1979a, b, c). The decidua and deciduoma have a limited life-span and the tissue regresses after approximately 2 weeks (Velardo, Dawson, Olsen \& Hisaw, 1953; De Feo, 1967). 
In spite of these investigations, however, the mechanisms involved in the development and regression of decidual tissue have not been determined. Progress in this area may be facilitated by the development of in-vitro systems of decidual cell differentiation. Decidualization in vitro has been reported for endometrial stem cells from hormone-treated ovariectomized rats (Sananes, Weiller, Baulieu \& Le Goascogne, 1978) and from pseudopregnant rats treated intraluminally with pyrathiazine hydrochloride (Vladimirsky, Chen, Amsterdam, Zor \& Lindner, 1977). In these reports endometrial cells were hormonally sensitized in vivo prior to culture, and although evidence for decidual cell differentiation in these cultures was presented, major differences in cell morphology were apparent. In the present study we report the establishment of an in-vitro system demonstrating decidual differentiation of mouse endometrial cells and provide a possible explanation for the discrepancies in the previous reports.

\section{Materials and Methods}

\section{Animals}

The inbred mouse strains $\mathrm{CBA} / \mathrm{Ca}$ and $\mathrm{A}$ were used. Cyclic 3-month-old females were paired with males of proven fertility and the morning on which a copulatory plug was found was designated Day 1 of pregnancy. On Day 4 between 12:00 and 15:00 h these animals were injected intraluminally with $10 \mu \mathrm{l}$ arachis oil (Hopkin \& Williams, Chadwell Heath, Essex, U.K.) per uterine horn, to induce deciduoma formation. Other groups of 3-month-old females were ovariectomized under ether anaesthesia 14 days before experimental treatment. One group of animals received oestradiol daily for 3 consecutive days and after a rest period of 3 days received oestradiol (10 ng) and progesterone (1 mg) daily for 3 consecutive days, both hormones being administered s.c. in $0.1 \mathrm{ml}$ arachis oil (Ledford et al., 1976). Animals in a second group were treated with progesterone only for 3 consecutive days and those in a third group received no hormones. Hormone-treated animals were injected intraluminally with $10 \mu \mathrm{l}$ arachis oil $24 \mathrm{~h}$ after the final hormone injection. Animals were killed by cervical dislocation at 0,24 and $48 \mathrm{~h}$ after instillation of oil. Some animals were killed $24 \mathrm{~h}$ after the final hormone injection without injection of oil. The animals receiving no hormones were killed between 16 and 28 days after ovariectomy.

\section{Cultures}

For each culture, uterine horns of 3-4 mice were dissected under sterile conditions, cleared of fat and placed in Dulbecco A and B phosphate-buffered saline (DPBS). They were rinsed three times in $10 \mathrm{ml}$ DPBS and subsequently thoroughly minced with iridectomy scissors. The fragments were resuspended three times in fresh DPBS each time, allowing the pieces of tissue to settle before discarding the supernatant, and $10 \mathrm{ml}$ prewarmed $\left(37^{\circ} \mathrm{C}\right) 0.1 \%$ trypsin solution (Difco Laboratories, P.O. Box 14B, West Molesey, Surrey, U.K.) was then added to the fragments in a conical test tube and agitated by pipetting. The fragments were then incubated for 30 min with continuous magnetic stirring at room temperature. The suspension was again pipetted, then left undisturbed until the largest fragments had sedimented and the supernatant was passed through a fine silk gauze. The filtrate was collected in a Petri dish containing $1 \mathrm{ml}$ RPMI-1640 (Gibco (Europe), Paisley, U.K.) containing L-glutamine $(0.3 \mathrm{mg} / \mathrm{ml})$, benzyl penicillin $(0.06 \mathrm{mg} / \mathrm{ml})$, and streptomycin sulphate $(0.05 \mathrm{mg} / \mathrm{ml})$, supplemented with $10 \%$ heat-inactivated fetal calf serum and buffered to $\mathrm{pH} 7.2$ with $2 \mathrm{mg}$ sodium bicarbonate per $\mathrm{ml}$, to inhibit the trypsinization. The filtrate was then transferred to a conical test tube and the cells were pelleted by centrifugation at $500 \mathrm{~g}$ for $5 \mathrm{~min}$. The pellet was resuspended in $0.5 \mathrm{ml}$ RPMI-1640 + $4.5 \mathrm{ml} 0.83 \% \mathrm{NH}_{4} \mathrm{Cl}$ and incubated for $10 \mathrm{~min}$ at room temperature to lyse any contaminating red blood cells. After centrifugation at $800 \mathrm{~g}$ for $5 \mathrm{~min}$ the pellet was washed 
sequentially with DPBS and RPMI-1640 medium (1:1 v/v) and DPBS, and the cells finally resuspended in RPMI-1640 medium, counted in a haemocytometer and diluted to obtain the appropriate cell concentration. Aliquots of $0.4 \mathrm{ml}$ suspension were added to the wells of leucocyte migration plates (Sterilin, Teddington, Middlesex, U.K.) and incubated at $37^{\circ} \mathrm{C}$ in a humid atmosphere at $5 \% \mathrm{CO}_{2}$ in air. Fresh medium was used after 24 and $48 \mathrm{~h}$ and then twice a week.

\section{Light and electron microscopy}

Cultures were examined daily with a Wild inverted microscope under phase-contrast optics. At various times plates were rinsed and fixed in absolute alcohol for $45 \mathrm{~min}$ and, after drying, stained with diluted Giemsa solution $(1: 10)$ for $45 \mathrm{~min}$. Numbers of cells within microscopic fields were measured using a $1-\mathrm{cm}$ square graticule and nuclear diameters of all cells were determined using a $1-\mathrm{cm}$ graticule subdivided into $0.1 \mathrm{~mm}$ divisions. Approximate nuclear area (a) was estimated using the formula, $a=\left(\pi \cdot d_{1} \times d_{2}\right) / 4$, in which $d_{1}$ and $d_{2}$ are the largest and smallest diameters of the nucleus respectively (Barlow \& Sherman, 1972). Other estimates, such as the number of cells and the incidence of polynucleated cells, were based on examination of at least 4 different culture dishes, derived from at least 3 experiments. Light micrographs were obtained of the stained preparations.

Cultures of mouse uterine cells were processed for electron microscopy after different periods in vitro. Cells were fixed in ice-cold cacodylate-buffered $4 \%$ glutaraldehyde, $\mathrm{pH} 7 \cdot 2$, for $4 \mathrm{~h}$, washed for $16 \mathrm{~h}$ at $0-4{ }^{\circ} \mathrm{C}$ in cacodylate-buffered $0.25 \mathrm{M}$-sucrose and post-fixed in phosphate-buffered $1 \%$ osmium tetroxide. The monolayers were dehydrated in ethanol, incubated for $4 \mathrm{~h}$ at $37^{\circ} \mathrm{C}$ in alcohol: Epon 812 solution $(1: 1 \mathrm{v} / \mathrm{v})$, and embedded by addition of Epon 812 directly into the culture wells. After hardening of the Epon, the plastic wells were removed by snap-freezing in liquid nitrogen or by trimming. Thin sections were stained with lead tartrate and examined in a Philips EM 300 electron microscope at an accelerating voltage of $89 \mathrm{kV}$.

\section{Results}

\section{Cultures of uterine cells from intact animals}

The number of uterine cells obtained by enzyme digestion increased from $1.5 \pm 0.4 \times 10^{5}$ cells per uterus at $0 \mathrm{~h}, 3.8 \pm 0.7 \times 10^{5}$ cells per uterus at $24 \mathrm{~h}$ to $6.3 \pm 1.3 \times 10^{5}$ cells per uterus at $48 \mathrm{~h}$ after intraluminal instillation of arachis oil. The plating efficiency of uterine cells, as determined by seeding 6 plates with $1.0 \times 10^{5}$ cells each and subsequent examination after $24 \mathrm{~h}$, increased from $24 \pm 9 \%$ at $0 \mathrm{~h}, 45 \pm 14 \%$ at $24 \mathrm{~h}$ to $95 \pm 4 \%$ at $48 \mathrm{~h}$ after intraluminal instillation of oil. Cells attached to the plates within $12 \mathrm{~h}$ of seeding and formed monolayers.

In most cultures two populations of mononucleate cells were observed. The major population consisted of dispersed, flat, splindle-shaped or stellate cells and exhibited great changes in culture (Pl. 1, Figs 1-4). The second population of cells, which occurred in low and variable numbers, were round, approximately 8-10 $\mu \mathrm{m}$ in diameter, and did not appear to undergo alterations during culture (Pl. 1, Figs 1-3). A third population of colony-forming cells was observed, but only rarely, in cultures of cells obtained $0 \mathrm{~h}$ after intraluminal instillation of arachis oil into uteri of CBA/Ca animals (Pl. 1, Fig. 5). They were more frequently observed in cultures of cells obtained from strain $\mathrm{A}$ females and were identical to the colonies observed in cultures of cells obtained from ovariectomized females. Subsequent observations refer only to the flat stellate cells.

After $24 \mathrm{~h}$ in culture cells obtained at different times after oil instillation appeared morphologically different. Cells obtained at $0 \mathrm{~h}$ after oil instillation were homogeneous in 
appearance after $24 \mathrm{~h}$ in culture, with single oval nuclei of uniform size and little cytoplasmic area (Pl. 1, Fig. 1). Cells obtained $24 \mathrm{~h}$ after oil instillation possessed increased cytoplasmic volume and larger oval nuclei (Pl. 1, Fig. 2). For cells obtained $48 \mathrm{~h}$ after oil instillation, the increase in cytoplasmic volume was most dramatic; the size of the nuclei was further increased (Pl. 1, Fig. 3) and they were often irregular in shape. Binucleate cells were also observed. It was apparent that these alterations in cells after $24 \mathrm{~h}$ in culture reflected changes occurring in vivo after oil instillation.

Cell density. Considerable alterations were observed during long-term culture of uterine cells, but these appeared to be dependent upon the original seeding density. As shown in Text-fig. 1 , at a seeding density of $0.5 \times 10^{5}$ (plating density at $24 \mathrm{~h}=75$ cells $/ \mathrm{mm}^{2}$ ) cell loss occurred throughout the culture period and very few binucleate cells were observed. The remaining cells, however, grew to a large size (PI. 1, Fig. 4), and their large single nuclei contained many pleomorphic dense inclusions. At a seeding density of $1.0 \times 10^{5}$ (plating density at $24 \mathrm{~h}=140$ cells $/ \mathrm{mm}^{2}$ ) the cell number remained at a steady state for 3 days before cell loss occurred (Text-fig. 1). An increase in cytoplasmic volume and nuclear area was observed, resulting in a paucity of intercellular space, and binucleated cells also occurred after 3 days (maximum $2 \cdot 5 \%$ ). Increasing the seeding density to $1.5 \times 10^{5}$ (plating density at $24 \mathrm{~h}=215$ cells $/ \mathrm{mm}^{2}$ ) resulted in further prolongation of cell survival, cell loss now being observed after 6-9 days of culture and a substantial increase in the number of binucleated cells on the third day (maximum 9\%). No net increase in cell number was observed until the seeding density was $5 \times 10^{5}$ (plating density at 24

\section{PLATE}

Uterine cells explanted from mice at 0,24 , or $48 \mathrm{~h}$ after intraluminal instillation of arachis oil, seeded at $0.2 \times 10^{5}-5 \times 10^{5}$ cells $/ \mathrm{mm}^{2}$ and examined after $1,3,6$ or 9 days in culture.

Fig. 1. Cells at $0 \mathrm{~h}, 1 \times 10^{5} / \mathrm{mm}^{2}$ and 1 day. Flat cells are mononuclear and small nuclei are surrounded by a small rim of cytoplasm. The arrowed cell is of the second population of small round cells. $\times 145$.

Fig. 2. Cells at $24 \mathrm{~h}, 0.5 \times 10^{5} / \mathrm{mm}^{2}$ and 1 day. Note the increased nuclear and cytoplasmic area of the flat cells. The arrowed cell is a small round cell. $\times 145$.

Fig. 3. Cells at $48 \mathrm{~h}, 0.2 \times 10^{5} / \mathrm{mm}^{2}$ and 1 day. Note the further increase in nuclear and cytoplasmic area of the flat cells. The arrowed cell is a small round cell. $\times 145$.

Fig. 4. Cells at $24 \mathrm{~h}, 0.5 \times 10^{5} / \mathrm{mm}^{2}$ and 9 days. There is a dramatic increase in nuclear and cytoplasmic area. $\times 145$.

Fig. 5. Cells at $0 \mathrm{~h}, 1 \times 10^{5} \mathrm{~mm}^{2}$ and 9 days. These are colony-forming mononuclear cells; the binuclear flat stellate cell (arrow) was rarely observed. $\times 145$.

Fig. 6. Cells at $48 \mathrm{~h}, 5 \times 10^{5} / \mathrm{mm}^{2}$ and 3 days. The cells shown are in an area of low density and a binuclear cell is arrowed. $\times 145$.

Fig. 7. Cells at $24 \mathrm{~h}, 1 \times 10^{5} / \mathrm{mm}^{2}$ and 6 days. Many of the cells have multilobular nuclei (arrowed). $\times 353$.

\section{PLATE 2}

Fig. 8. Low-power electron micrograph of typical decidualized mouse uterine cells obtained from uteri $24 \mathrm{~h}$ after intraluminal instillation of arachis oil, and after $96 \mathrm{~h}$ in culture showing the general arrangement of the cell contents. The nucleus contains a prominent nucleolus and the rough endoplasmic reticulum with attached polysomes is well developed and contains an electron-dense homogeneous material. The polysomes also display flat spiral configurations (arrowed). $\times 20000$.

Fig. 9. After $96 \mathrm{~h}$ in culture decidualized cells frequently contain nuclei with bizarre and irregular forms. $\times 20000$.

Fig. 10. Decidualized cells at $96 \mathrm{~h}$ in vitro commonly contain extensive amounts of filamentous material within the cytoplasm. $\times 40000$. 


\section{PLATE 1}
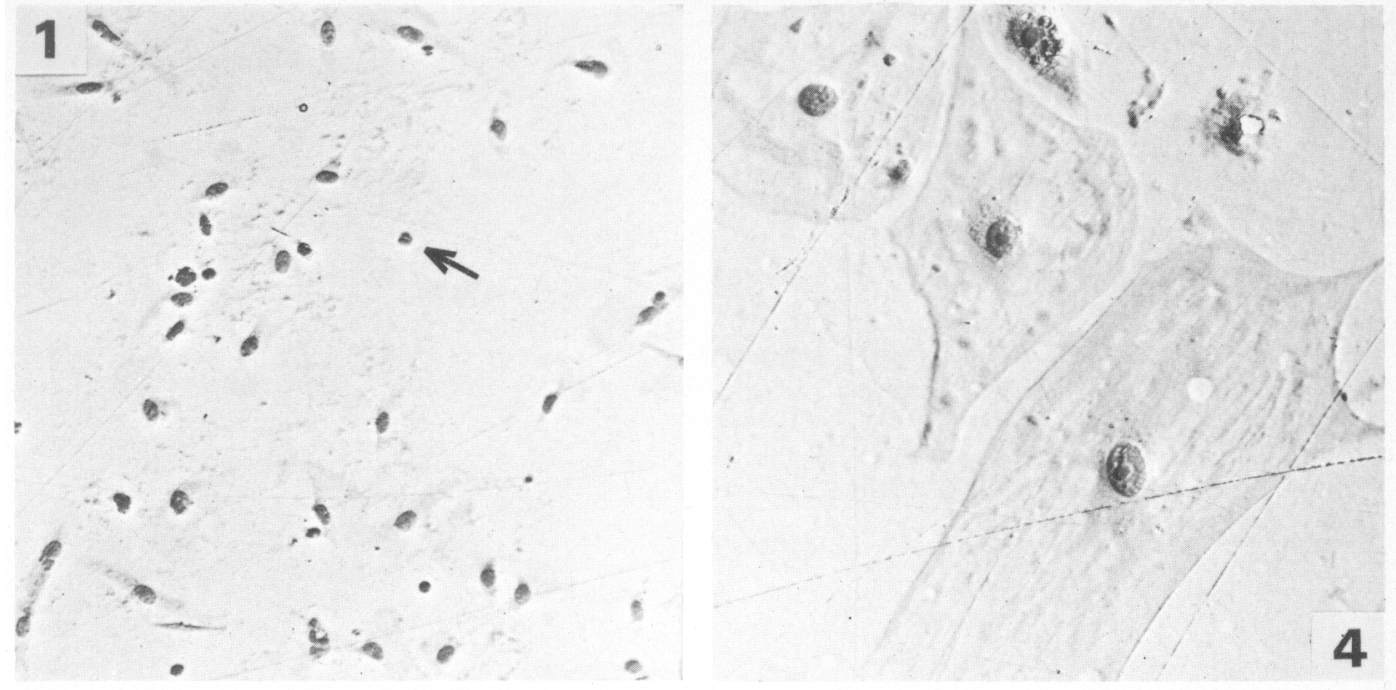

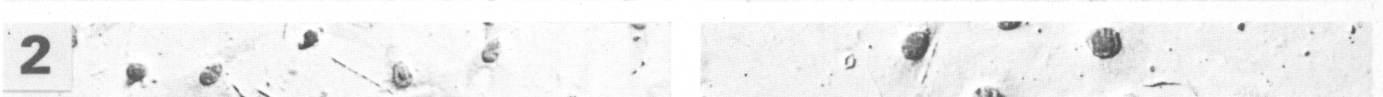

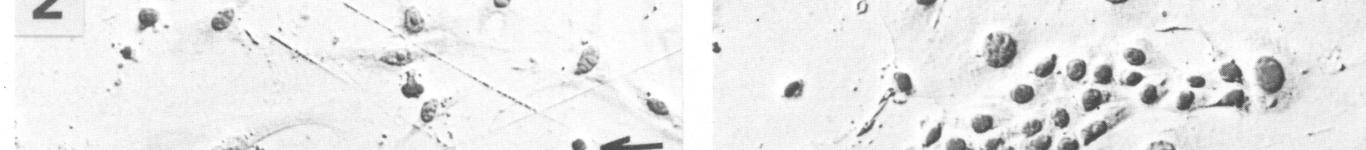

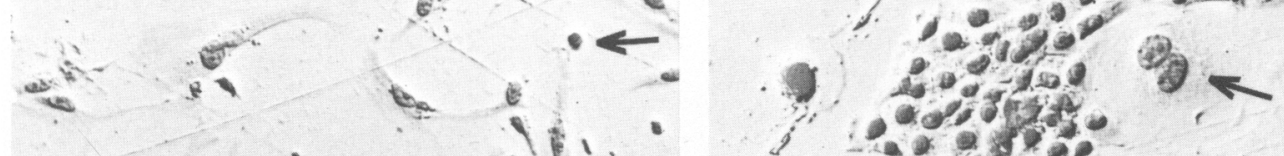

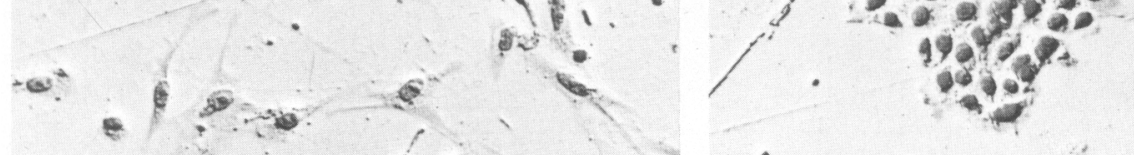

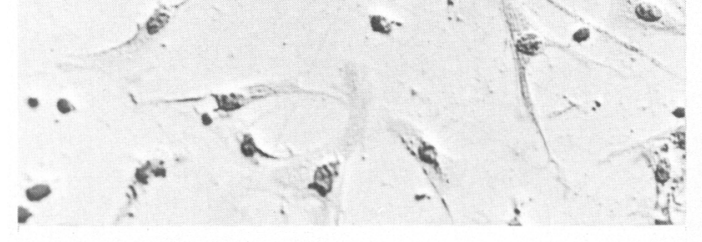

$38.68 \%$
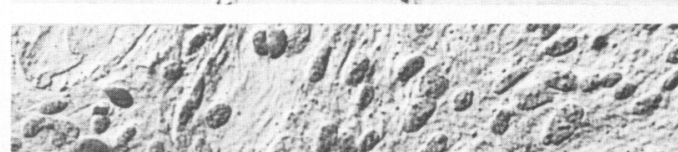

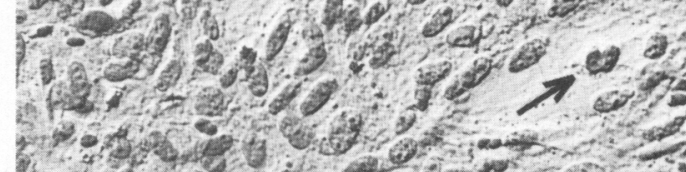

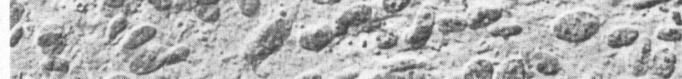

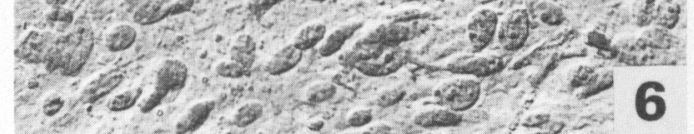

$\therefore 6$ a
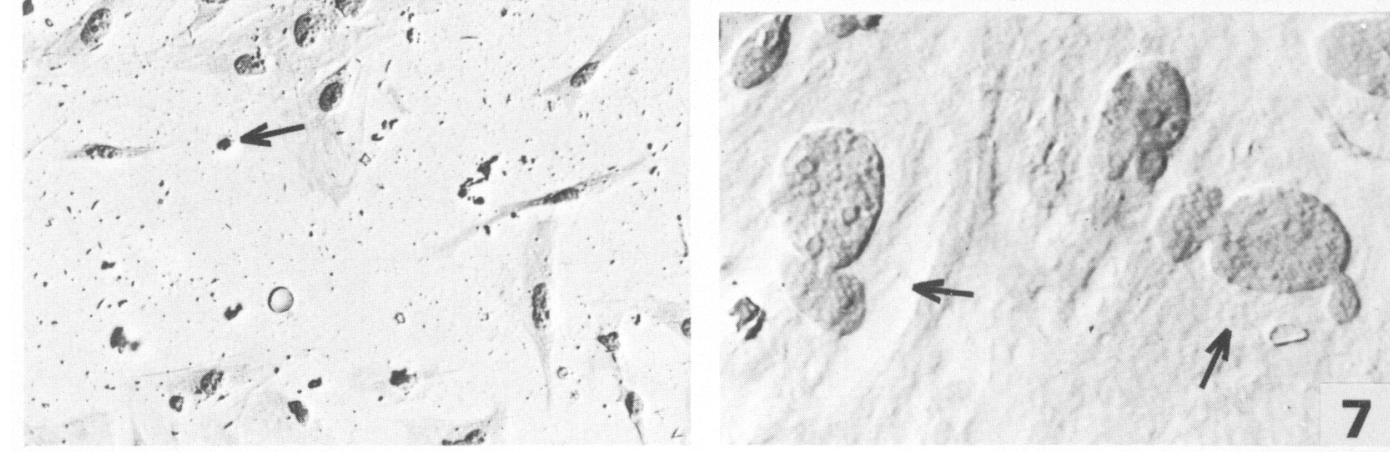
PLATF 2

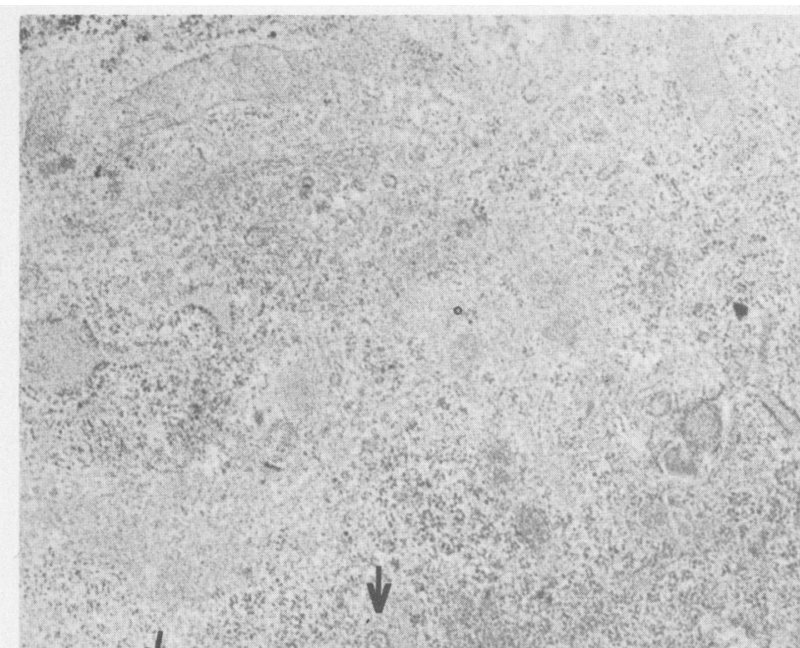

$\downarrow$

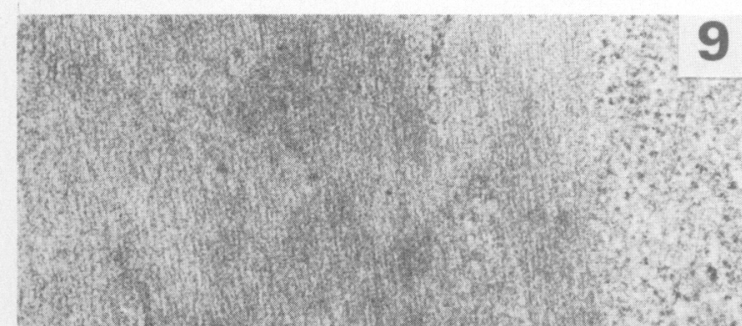

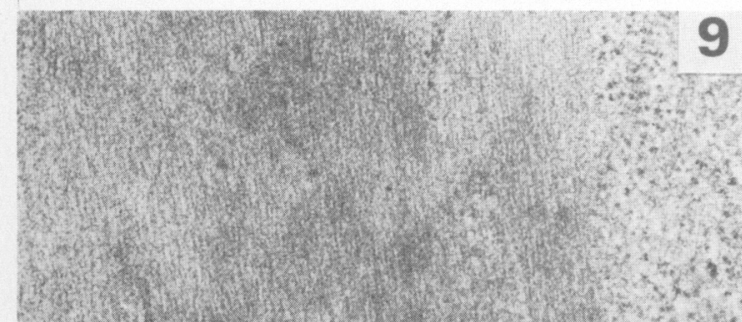

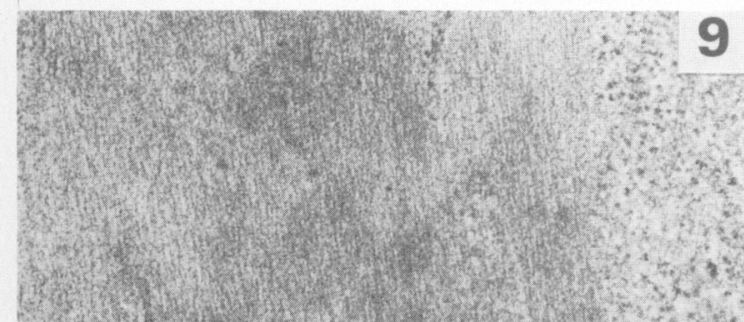

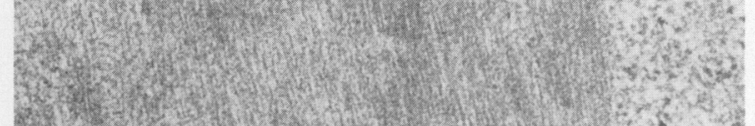

$$
\begin{aligned}
& \text { W. }
\end{aligned}
$$

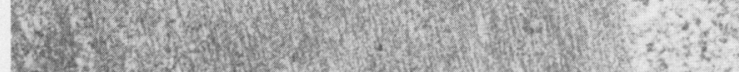

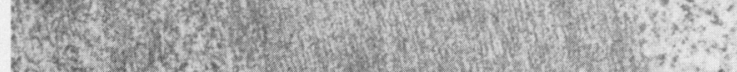

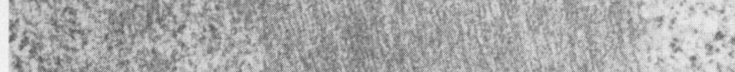$$
\text { H. }
$$

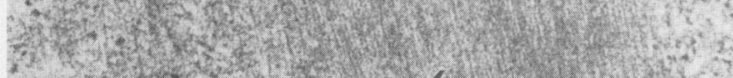

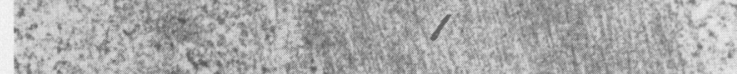

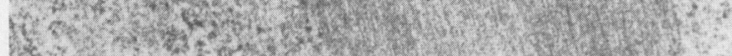

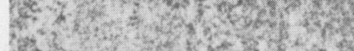

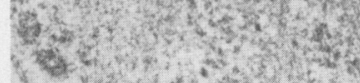
Fo

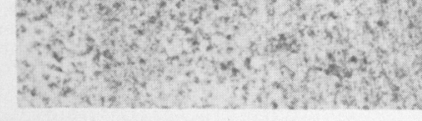
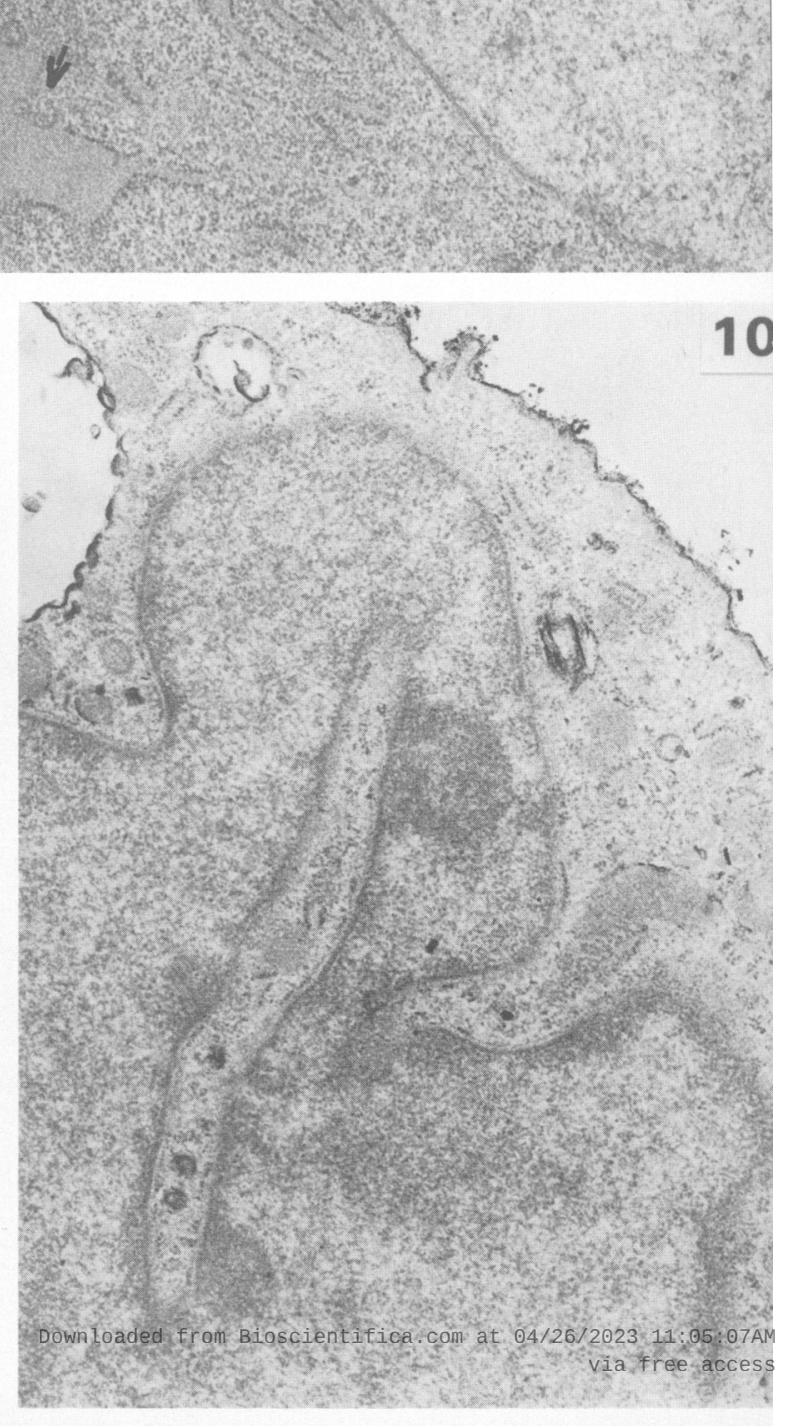


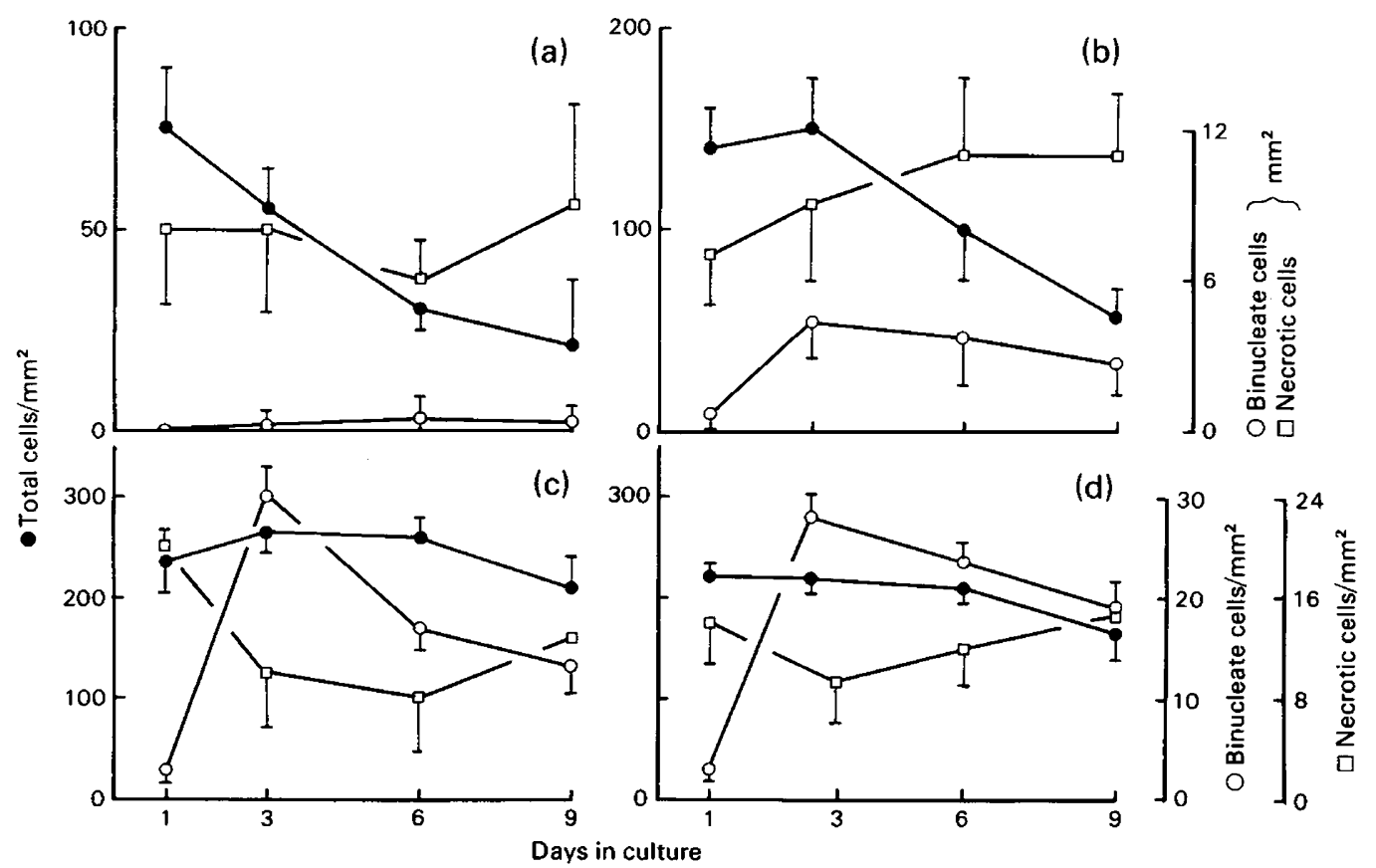

Text-fig. 1. Mean \pm s.e.m. numbers of total cells $(O)$, necrotic cells $(\square)$ and binucleated cells (O) in cultures of mouse uterine cells obtained from $24 \mathrm{~h}$ after the intraluminal instillation of arachis oil and seeded at (a) $0.5 \times 10^{5}$, (b) $1.0 \times 10^{5}$, and (c, d) $1.5 \times 10^{5}$ cells $/ \mathrm{mm}^{2}$. For (d) $10^{-7}$ M-progesterone was added to the culture medium.

$\mathrm{h}=709$ cells $/ \mathrm{mm}^{2}$ ), when after $48 \mathrm{~h}$ of culture several overlapping layers of cells were obtained, making accurate cell counting impossible (PI. 1, Fig. 6). In the less densely plated zones many binucleate cells were observed. Signs of degeneration appeared after 9 days in culture and, as with all the cultures, complete involution occurred by 14-21 days. Although these data were obtained with uterine cells obtained $24 \mathrm{~h}$ after intraluminal instillation of oil a similar relationship was observed with all uterine cells, irrespective of time of collection, and also with cells obtained from animals which received no oil injection.

Electron microscopy. The cultures of uterine cells displayed essentially similar fine structural features throughout the entire period of study. Some cells were binucleated and contained large regular-shaped nuclei with prominent nucleoli (PI. 2, Fig. 8). Small quantities of condensed chromatin lined the inner nuclear membranes. After $96 \mathrm{~h}$ in culture irregularly shaped nuclei characterized by deep cytoplasmic protrusions were frequently observed (Pl. 2, Fig. 10).

Within the cytoplasm large amounts of filamentous material were distributed amongst the cytoplasmic organelles and appeared to be arranged into tracts of filaments running in several planes (Pl. 2, Fig. 9). Mitochondria and numerous free polysomes were the only cytoplasmic organelles observed in these filamentous areas. An identical arrangement of cytoplasmic filaments characterizes mouse decidual tissue in vivo (R. F. Searle, unpublished observations). The cisternae of the well-developed rough endoplasmic reticulum were often dilated and contained an electron-dense homogeneous material (PI. 2, Fig. 8). Numerous free polysomes were also present in the cytoplasm and flat spiral polysomes were observed attached to the rough endoplasmic reticulum (Pl. 2, Fig. 8). In some cells, the Golgi zones were well developed. After periods of culture in excess of $96 \mathrm{~h}$ there was a marked accumulation of small lipid droplets, lysomes and autophagic vacuoles within the cytoplasm. 
Nuclear size. To obtain a measure of the incidence and the degree of polyploidy in the cell cultures estimations of nuclear area were made. The nuclear area of cells explanted $0 \mathrm{~h}$ after intraluminal instillation of oil increased 4-fold during 6 days of culture (170 \pm 10 (s.e.m.) versus $680 \pm 40 \mu \mathrm{m}^{2}, P<0.001$ ). As shown in Text-fig. 2, although the range of nuclear area was narrow on Day 3 of culture, after 6 days a wide range of sizes was observed up to $1000-1600$ $\mu \mathrm{m}^{2}$. Cells explanted at $24 \mathrm{~h}$ possessed a higher mean nuclear area after the first day in culture $\left(290 \pm 50 \mu \mathrm{m}^{2}\right)$, and achieved a similar maximum size after only 3 days in culture $(650 \pm 50$ $\mu \mathrm{m}^{2}$; Table 1). However, at the higher seeding density of $5 \times 10^{5}$, which resulted in net growth, a mean nuclear diameter of only $470+30 \mu \mathrm{m}^{2}$ was observed during culture of cells explanted from uteri $48 \mathrm{~h}$ after intraluminal instillation of arachis oil.

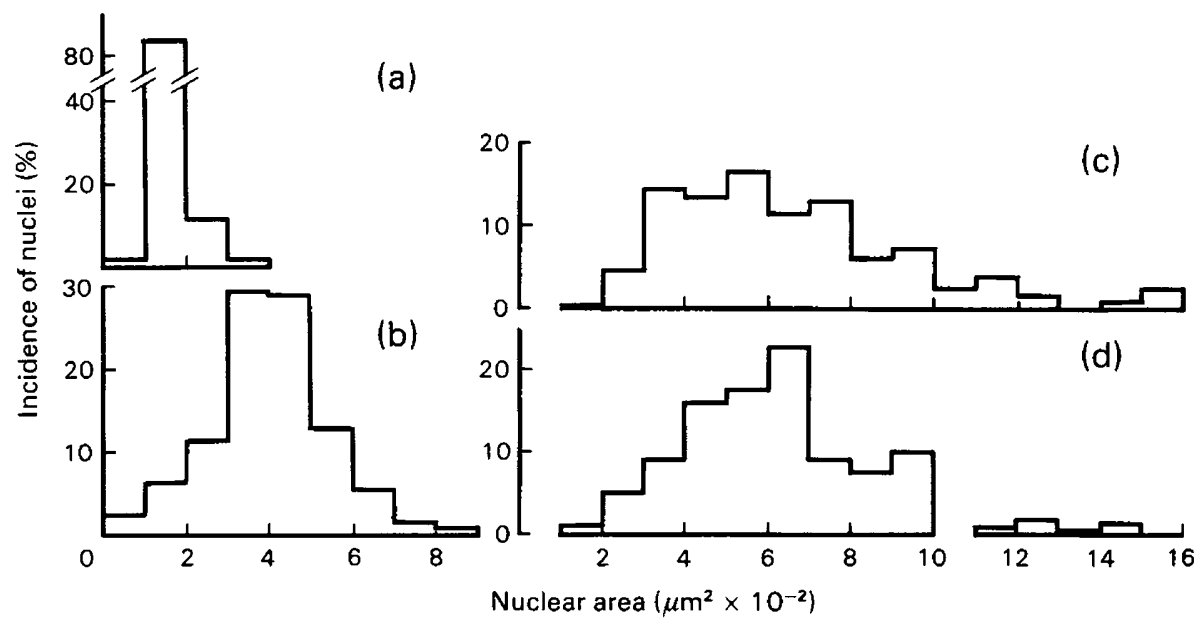

Text-fig. 2. Frequency distribution of nuclear area in cultures of mouse uterine cells explanted 0 $\mathrm{h}$ after intraluminal instillation of arachis oil, seeded at $1 \times 10^{5} \mathrm{cells} / \mathrm{mm}^{2}$ and examined at (a) 1 day, (b) 3 days, (c) 6 days and (d) 9 days after seeding. Nuclear area was calculated for 200 nuclei in each group.

Table 1. Nuclear area of mouse uterine cells during culture

\begin{tabular}{cccccc}
\hline \multirow{2}{*}{$\begin{array}{c}\text { Time after } \\
\text { oil instillation } \\
\text { (h) }\end{array}$} & $\begin{array}{c}\text { Seeding } \\
\text { density }\end{array}$ & \multicolumn{4}{c}{ Nuclear area $\left(\mu \mathrm{m}^{2} \times 10^{-2}\right)$ after culture for: } \\
\cline { 3 - 6 } & (cells/plate) & 1 day & 3 days & 6 days & 9 days \\
\hline 0 & $1 \times 10^{5}$ & $1.7 \pm 0.1$ & $4.1 \pm 0.1$ & $6.8 \pm 0.4$ & $6.6 \pm 0.3$ \\
24 & $1 \times 10^{5}$ & $2.9 \pm 0.5$ & $6.5 \pm 0.5$ & $6.5 \pm 0.5$ & $6.0 \pm 0.5$ \\
24 & $5 \times 10^{5}$ & $2.8 \pm 0.5$ & $4.7 \pm 0.3$ & $4.6 \pm 0.7$ & $4.7 \pm 0.6$ \\
48 & $1 \times 10^{5}$ & $5.4 \pm 0.6$ & $6.4 \pm 0.5$ & $6.4 \pm 0.6$ & $6.1 \pm 0.7$ \\
\hline
\end{tabular}

Values are mean \pm s.e.m. for 200 nuclei.

The number of nucleoli, which stained densely with Giemsa, varied from 1 to 6 per nucleus, and were larger when there were fewer. Nuclei from cells explanted at 0 to $24 \mathrm{~h}$, after 6 days in culture, and at $48 \mathrm{~h}$ after 3 days, became multi-lobular and very irregular in shape (Pl. 1, Fig. 7; Pl. 2, Fig. 8).

Effect of hormone supplementation. To determine whether the rate of division or the life-span of decidual cells in culture could be increased, the culture medium was supplemented with approximately physiological concentrations of oestrogen $\left(10^{-9} \mathrm{M}\right)$ and progesterone $\left(10^{-7} \mathrm{M}\right)$, the hormones involved with the induction of the decidual cell reaction and the maintenance of decidual tissue in vivo. Addition of these hormones had no effect upon any of the parameters examined in this study. 


\section{Cultures of uterine cells from ovariectomized mice}

Uterine cells from ovariectomized animals gave rise to two types of cells in culture, small colonies of epithelial cells and dispersed fibroblast-like cells. The colonies were composed of 10-50 cells forming a continuous 'crazy-paving' sheet, and possessed a single nucleus of area $170 \pm 8 \mu \mathrm{m}^{2}$, although an occasional binucleated cell was observed. These colonies were identical to the occasional colony observed in cultures of cells obtained from uteri after the instillation of oil (Pl. 1, Fig. 5). No indications of the changes previously observed were detected in these cultures even after 10 days. The fibroblast-like cells remained unaltered in morphology during culture. Uterine cells from hormone-treated animals, however, underwent morphological changes similar to those in cultures of uterine cells from pregnant uteri.

\section{Discussion}

Cells explanted from the uteri of pregnant or hormone-primed ovariectomized mice underwent characteristic morphological transformations in vitro. The type of morphologically distinct cell observed depended upon the seeding density of the uterine cells, but both cell types were considered to represent differentiated decidual cells. The typical decidual cellular characteristics observed included binucleation and polyploidy, accumulation of filamentous material, increased number of lysosomes, development of Golgi apparatus, dilatation of rough-surfaced endoplasmic reticulum and numerous polysomes (Jollie \& Bencosme, 1965; Tachi et al., 1970; Ansell, Barlow \& McLaren, 1974; Sananes \& Le Goascogne, 1976). Nuclei of bizarre shape and lobulated have not been recorded in previous in-vitro studies (Vladimirsky et al., 1977; Sananes et al., 1978), but have been observed in vivo in the pseudopregnant deciduoma-bearing rat (Kleinfeld, Morrow \& De Feo, 1976). In both morphological types an increase in the DNA content of the cells may be surmised-at the lower densities, the dramatic increase in the area of the single nucleus which correlates with the degree of ploidy (Barlow \& Sherman, 1972), and at the higher densities when binucleation was observed. The former probably arise through endoreduplication (Ansell et al., 1974; Leroy et al., 1974) and the latter through karyokinesis without subsequent cell division (Ansell et al., 1974).

In vivo, decidualization in appropriately hormone-primed animals requires the application of a 'decidual stimulus'. It is possible that the uteri from the pregnant animals had received a decidual stimulus from unimplanted blastocysts although this would not apply to the hormone-primed ovariectomized animals. As in previous reports, the observation of decidual differentiation in cells explanted from unstimulated uteri indicates that the experimental procedure employed to isolate uterine cells must be equivalent to the decidual stimulus in vivo (Vladimirsky et al., 1977; Sananes et al., 1978). The apparent independence of decidual differentiation in vitro from the presence of progesterone is difficult to explain since maintenance of decidualization in vivo exhibits complete dependence upon the presence of this hormone (Finn, 1971; Psychoyos, 1973; Glasser \& Clark, 1975). The inability to maintain cultures beyond $1 \frac{1}{2}$ weeks, the maximum development at optimal seeding density being obtained after 6 days reflects the situation in vivo, supporting the concept that decidual regression in vivo is due to the limited life-span of decidual cells.

The only previous reports of decidualization of endometrial and uterine cells in vitro have been from studies of rats, in which markedly different, morphologically distinct cellular types have been obtained. Sananes et al. (1978), using uterine cells from hormonally-primed spayed rats, observed binucleated cells which exhibited no contact inhibition and underwent degeneration after 6 days. Net growth was reported. Vladimirsky et al. (1977) explanted endometrial cells from pseudopregnant rat uteri at timed intervals after the induction, of the decidual cell reaction with pyrathiazine, and these developed into populations of dispersed spindle-shaped or stellate cells and colonies of closely packed polygonal cells. A net increase in 
the number of cells was only observed within the colonies, which also became bi- and multinucleated. The dispersed cells exhibited a doubling in nuclear area and a substantial increase in cytoplasmic volume. Both these reports considered that the cells were decidual cells on the basis of their polyploidy and/or binucleation and accumulation of filamentous material. These apparent discrepancies in cellular morphology could have been due to the different physiological condition of the uterine stem cells. However, a more likely explanation could be related to the different seeding densities employed. Sananes et al. (1978) seeded uterine cells at a density of 1000 cells $/ \mathrm{mm}^{2}$, which was equivalent to the highest densities used in the present study, when we obtained a similar decidual cell morphology and characteristics. Vladimirsky $e t$ al. (1977) seeded endometrial cells at a density of 55 cells $/ \mathrm{mm}^{2}$, equivalent to the lower densities used in the present study, and obtained stellate cells identical to those described here. However, we observed colony-forming cells rather infrequently, and due to their similarity to the colony-forming cells found in cultures of uteri from ovariectomized mice we consider these to be epithelial cells. Luminal epithelial cells, after being exposed to the hormone regimen necessary for implantation and a decidual stimulus, exhibit 'programmed cell death' (Finn \& Porter, 1977). According to the method of induction employed, epithelial cells may escape this mechanism and give rise to viable stem cells.

The ability to obtain reproducible decidual cell differentiation in vitro in the mouse provides the opportunity to investigate a number of outstanding problems associated with decidualization, such as the synthesis of decidual cell specific products (Bell, 1979a, b) and the identity of the Ia-bearing cells in the decidua basalis (Jenkinson \& Searle, 1979).

We thank Dr W. D. Billington for stimulating discussions and criticisms, Mrs D. Keane for help in the preparation of the manuscript, and $\mathrm{Mr} \mathrm{C}$. Jeal for photographic expertise. The work was supported by grants from The Rockefeller Foundation and the Medical Research Council.

\section{References}

Ansell, J.D., Barlow, P.W. \& McLaren, A. (1974) Binucleated polyploid cells in the decidua of the mouse. J. Embryol. exp. Morph. 31, 223-227.

Barlow, P.W. \& Sherman, M.I. (1972) The biochemistry of differentiation of mouse trophoblast: studies on polyploidy. J. Embryol. exp. Morph. 27, 447-465.

Bell, S.C. (1979a) Protein synthesis during deciduoma morphogenesis in the rat. Biol. Reprod. 20, 811-821.

Bell, S.C. (1979b) Synthesis of 'decidualization-associated protein' in tissues of the rat uterus and placenta during pregnancy. J. Reprod. Fert. 56, 255-262.

Bell, S.C. (1979c) Immunochemical identity of 'decidualization-associated protein' and $\alpha_{2}$ acutephase macroglobulin in the pregnant rat. J. Reprod. Immunol. 1, 193-206.

De Feo, V.J. (1967) Decidualization. In Cellular Biology of the Uterus, pp. 191-290. Ed. R. M. Wynn. Appleton-Century-Crofts, New York.

Denari, J.H., Germino, N.I. \& Rosner, J. M. (1976) Early synthesis of uterine proteins after a decidual stimulus in the pseudopregnant rat. Biol. Reprod. 15, $1-8$.

Finn, C. A. (1971) The biology of decidual cells. Adv. Reprod. Physiol. 15, 1-26.

Finn, C.A. \& Porter, D.G. (1977) The Uterus. Elek Scientific Books Ltd, London.

Glasser, S.R. \& Clark, J.H. (1975) A determinant role for progesterone in the development of uterine sensitivity to decidualization and ovo-implantation. In Developmental Biology of Reproduction, pp. 311-345. Eds C. L. Market \& J. Papaconstantiou. Academic Press, New York.

Jenkinson, E.J. \& Searle, R.F. (1979) Ia antigen expression on the developing mouse embryo and placenta. J. Reprod. Immunol. 1, 3-10.

Jollie, W.P. \& Bencosme, S.A. (1965) Electron microscopic observation on primary decidua formation in the rat. Am. J. Anat. 116, 217-236.

Kleinfeld, R.G., Morrow, H.A. \& De Feo, V.J. (1976) Intercellular junctions between decidual cells in the growing deciduoma of the pseudopregnant rat uterus. Biol. Reprod. 15, 593-603.

Krehbiel, R.H. (1937) Cytological studies of the decidual reaction in the rat during early pregnancy and in the production of deciduomata. Physiol. Zool. 10, 212-234.

Ledford, B.E., Rankin, J.C., Markwald, R.R. \& Baggett, B. (1976) Biochemical and morphological changes following artificially stimulated decidualization in the mouse uterus. Biol. Reprod. 15, 529-535.

Ledford, B.E., Rankin, J.C., Froble, V.L., Serra, M.J., Markwald, R.R. \& Baggett, B. (1978) The decidual cell reaction in the mouse uterus: DNA synthesis and autoradiographic analysis of response cells. Biol. Reprod. 18, 506-509. 
Leroy, F., Bogaert, C., Van Hoeck, J. \& Delcroix, C. (1974) Cytophotometric autoradiographic evaluation of cell kinetics in decidual growth in rats. $J$. Reprod. Fert. 38, 441-449.

Moulton, B.C. (1979) Effect of progesterone on DNA, RNA and protein synthesis of deciduoma cell fractions separated by velocity sedimentation. Biol. Reprod. 21, 667-672.

Moulton, B.C. \& Blaha, G.C. (1978) Separation of deciduomal cells by velocity sedimentation at unit gravity. Biol. Reprod. 18, 141-147.

Psychoyos, A. (1973) Hormonal control of ovo-implantation. Vitams Hom. 31, 201-256.

Rankin, J.C., Ledford, B.E. \& Baggett, B. (1977) Early involvement of cyclic nucleotides in the artificially stimulated decidual cell reaction in the mouse uterus. Biol. Reprod. 17, 549-554.

Sananes, N. \& Le Goascogne, C. (1976) Decidualization in the prepubertal rat uterus. Differentiation 5 , 133-144.

Sananes, N., Weiller, S., Baulieu, E.-E. \& Le Goascogne, C. (1978) In vitro decidualization of rat endometrial cells. Endocrinology 103, 86-95.
Serra, M.J., Ledford, B.E. \& Baggett, B. (1979) Synthesis and modification of the histones during the decidual cell reaction in the mouse uterus. Biol. Reprod. 20, 214-220.

Tachi, S., Tachi, C. \& Lindner, H.R. (1970) Ultrastructural features of blastocyst attachment and trophoblastic invasion in the rat. J. Reprod. Fert. 21, $37-56$.

Velardo, J.T., Dawson, A.B., Olsen, A.G. \& Hisaw, F.L. (1953) Sequences of histological changes in the uterus and vagina of the rat during prolongation of pseudopregnancy associated with the presence of deciduomata. Am. J. Anat. 93, 273-305.

Vladimirsky, F., Chen, L., Amsterdam, A., Zor, U. \& Lindner, H.R. (1977) Differentiation of decidual cells in cultures of rat endometrium. J. Reprod. Fert. 49, 61-68.

Yoshinaga, K. (1972) Rabbit antiserum to rat deciduoma. Biol. Reprod. 6, 51-57.

Yoshinaga, K. (1974) Interspecific cross-reactivity of deciduoma antiserum: interaction between mouse deciduoma and antiserum to rat deciduoma. Biol. Reprod. 11, 50-55. 